\title{
IS THERE A DIFFERENCE IN TERMS OF THE GIVEN IMPORTANCE OF MOTIVATORS THAT AFFECT JOB SELECTION DECISIONS BETWEEN DIFFERENT PERSONALITY TYPES? AN EMPIRICAL RESEARCH ${ }^{\star}$
}

\author{
FARKLI KIŞ̧ILIKK TİPLERİNE SAHİP BİREYLER ARASINDA İŞ SEÇİM \\ KARARINI ETKİLEYEN FAKTÖRLERE VERILLEN ÖNEM AÇISINDAN \\ ANLAMLI BİR FARK VAR MIDIR? GÖRGÜL BİR ARAŞTIRMA
}

\author{
Mehmet Nuri İnel** \\ M. Volkan Türker ${ }^{\star * \star}$
}

\begin{abstract}
This study explores whether the given importance of motivators that effect potential job selection decisions of university students changed depending on their personality type. An empirical research was conducted in order to answer this research question. All participants were Bachelor students in the Faculty of Business Administration of Marmara University, Turkey. Data collection was accomplished through a three-part questionnaire. The first part of the questionnaire was the demographic variables, the second part was related with Type-A and Type-B personality types and the last part was related with the motivators that effect students' potential job selection decisions. As a result, it was found that students with Type-A Behavior Pattern tended to give more importance to some motivators which effect their potential job selection decisions.
\end{abstract}

Keywords: Type-A Behavior Pattern, Type-B Behavior Pattern, Job Selection Decision

* This study was initially presented at 17th Eurasia Business and Economics Society Conference in Venice, Italy, October 15-17th, 2015. This study is also supported by Marmara University Scientific Research Project Coordination Unit (BAPKO) Project No: SOS-D-071015-0494.

** Asst. Prof. Dr. Marmara University, Faculty of Business Administration, Department of Business Administration, mninel@marmara.edu.tr

*** Assoc. Prof. Dr. Marmara University, Faculty of Business Administration, Department of Business Administration, vturker@marmara.edu.tr 


\section{Öz}

$\mathrm{Bu}$ araştırma, farklı kişilik tiplerine sahip bireyler arasında iş seçim kararını etkileyen faktörlere verilen önem açısından anlamlı bir farkın olup olmadığını incelemek amacını taşımaktadır. Bu amaçla, Marmara Üniversitesi İşletme Fakültesine kayıtlı lisans öğrencileri üzerine görgül bir saha araştırması tasarlanmış ve hayata geçirilmiştir. Sonuç olarak A-Tipi Kişilik Örüntüsüne sahip öğrencilerin, B-Tipi Kişilik Örüntüsüne sahip öğrencilere kıyasla iş seçim kararlarını etkileyen bazı faktörlere istatistiksel olarak anlamlı derecede daha çok önem vermekte oldukları tespit edilmiştir. Araştırmanın sonuç kısmında söz konusu faktörlerin neler olduğu ve neden A-Tipi Kişilik örüntüsünde bulunan öğrencilerin bu faktörlere daha çok önem verdikleri tartışılmıştır.

Anahtar Kelimeler: A-Tipi Kişilik Örüntüsü, B-Tipi Kişilik Örüntüsü, İ̧̧ Seçim Kararı

\section{Introduction}

Selecting a job can be difficult, people may be unsure of what is truly right for them. We know that there are many factors and motivators that affect the job selection decision of people. But is the importance of these factors are same for all people? Probably not. There must be some key factors that differs the given importance of motivators that affect the job selection decision. Personality may be one of them. This is the starting point of this study.

The first construct of this study is job selection decision. Many factors may affect the decisions of job seekers like; company culture, benefits, location, level of job security, size of company, nature of work, training provided and career opportunities, etc.

Personality type is the second construct of this study. There is no doubt that one of the major attributes influencing organizational behavior is personality type and the concepts of Type-A and Type-B Behavior Patterns has been receiving substantial attention in this area.

This study will try to find any significant difference in terms of Job Selection Decisions between Type-A and Type-B personalities. A field survey was conducted on undergraduate students.

\section{Theoretical Framework}

\section{Motivators that affect Job Selection Decisions}

The Human Resource Management (HRM) literature has largely describe job selection as a relatively rational and goal-directed behavior (Kulkarni and Nithyanand, 2013). But there is no doubt that job selection decision is a complex process for individuals. Lots of internal and external factors may affect this process. Wherein said 'selection factors' are not the ones used by organizations during 'hiring processes', they are the factors that affect the decision of individual in selecting a job to apply for.

Among these factors are job security, advancement opportunities, and autonomy. These preferences can also impact organizations through job selection decisions and employee retention (Corrigall, 2008). 
According to Aycan and Fikret-Pasa (2003), these factors are actually "motivators assessing the extent to which participants considered each as important in selecting a job or an employment setting".

\section{Type-A and Type-B Behavior Patterns}

Many studies have investigated the existence of the Type-A and Type-B Behavior Patterns in organizational behavior literature (Stewart-Belle and Lust, 1999). As an aspect of personality, Type-A and Type-B Behavior Patterns have been receiving substantial attention in this area (Billing and Steverson, 2013). Interestingly, these personality types of behavior patterns firstly described in 1959 by two cardiologists; Rosenman and Friedman instead of psychologists or behaviorists. Rosenman and Friedman found that "men possessing overt behavior pattern "A" also exhibited much higher serum cholesterol levels, more rapid blood clotting, higher incidence of arcus senilis (is a white, grey, or blue opaque ring in the corneal margin), and a seven-fold higher incidence of coronary heart disease than did either paired subjects exhibiting frank anxiety states, although again the dietary, drinking, smoking, and exercise habits of the three groups were comparable" (Rosenman and Friedman, 1961, p.1173).

Personality attribute in terms of A and B Types is explained as how people react when oppose the stressful threats and challenges in his or her daily life. People with Type-A Behavior Pattern react to the situation in a very aggressive, competitive, achievement oriented, hurriedly, confidently and impatient manner, While Type-B Behavior Pattern responds in a way characterized as careless, occasional, and unhurried in doing his or her assigned tasks (Byrne and Reinhart, 1989; Hanif and Sultan, 2011).

People, who are excessively competitive, strive achievement (Byrne and Reinhart, 1989; Erden, Toplu and Yaşlığlu, 2013) and always seem to be experiencing a constant sense of time urgency defined as Type-A Behavior Pattern (Rosenman and Friedman, 1961; Lee, et al. 1996; StewartBelle and Lust, 1999; Watson, et al. 2006; Billing and Steverson, 2013). Those people with a Type-A Behavior Pattern are, aggressively involved in a chronic, incessant struggle to achieve more and more in less and less time and if required to do so, against the opposing efforts of other things or other persons (Robbins, 1998, p.64).

According to Robbins (1998), people with Type-A Behavior Pattern always move, walk and eat rapidly, feel impatient with the rate at which most events take place, strive to think or to do two or more things at once, cannot deal with leisure time, obsessed with numbers, prefer to measure and evaluate success in terms of numbers, are poor delegators (Nahavandi, Mizzi and Malekzadeh, 1992), are idealist and perfectionist (Eren, 2000). In addition, more of the start-up entrepreneurs and founders have hard diving and aggressive Type-A profiles (Begley and Boyd, 1987, p.100).

The very opposite type of personality is Type-B. Those people with a Type-B Behavior Pattern are, rarely harried by the desire to obtain a wildly increasing number of things or participate in an endless growing series of events in an ever-decreasing amount of time (Robbins, 1998, pp.65). 
And they never suffer from a sense of time urgency with its accompanying impatience, they feel no need to display or discuss either their achievements or accomplishments unless such exposure is demanded by the situation, they play for fun and relaxation, rather than to exhibit their superiority at any cost, they can relax without guilt, they are easygoing, less nervous and have lots of friends for their support (Sameen and Burhan, 2014) and they take time for themselves and their families (Eren, 2000).

\section{Methodology}

\section{Sample and Data Collection}

Data were collected from a sample of undergraduate students attending Marmara University, Faculty of Business Administration, Department of Business Administration in İstanbul. These students were recruited through various classes with the permission of instructors.

In August 2015, a field survey was conducted on aforementioned undergraduate students during summer term. A questionnaire was prepared for the assessment of the main variables. The instrument administered to the students surveyed their attitudes and perceptions about their personality type and the motivators that effect their potential job selection decisions. The questionnaire was composed of 67 items in two scales. Respondents were additionally instructed to provide specific biographical information so they could be categorized by age, gender, and year of education.

A sample of 229 undergraduate students voluntarily completed the questionnaire in total. Questionnaires obtained from 20 students are eliminated because of missing or inconsistent data. Data obtained from those 209 questionnaires were analyzed through the SPSS statistical program and proposed hypotheses were tested through statistical analyses. $37.3 \%$ of the respondents are female and $62.2 \%$ are male.

As in every social science research, some limitations and constraints have been also come across in this research, too. The biggest limitation of the research is the sample size. A larger sample size from different universities will provide more accurate results.

\section{Hypotheses, Scales, Analyses and Results}

In order to measure the perceptions about personality types of students, 20-item Likert scale of Baltaş and Baltaş (2012) was used.

The importance they gave to the motivators that effect their potential job selection decisions were measured by the 25-item scale of Aycan and Fikret-Pasa (2003). This scale is an adaptation of the 48-item work rewards scale which developed by Kanungo and Hartwick (1987). Aycan and Fikret-Pasa identify those items as the "motivators assessing the extent to which participants considered each as important in selecting a job or an employment setting". The scale was converted to 5-point likert importance scale (Very Important, Important, Neither Important nor 
Unimportant, Unimportant, Very Unimportant) instead of Q-sort technique that was used by Aycan and Fikret-Pasa (2003).

Both scales were subjected to reliability testing using data collected in this study. In order to measure internal consistency (reliability) we used Cronbach's Alpha statistics. The results of reliability analysis are shown in Table 1 and 2. Two item from personality type scale was extracted in reliability analysis. One item of job selection decision scale was extracted in reliability analysis. These results indicate the reliability of scales used in this survey.

Table I. Reliability Statistics of Personality Type Scale

\begin{tabular}{ll}
\hline Cronbach's Alpha & N of Items \\
\cline { 2 - 2 } .697 & 18 \\
\hline
\end{tabular}

Table 2. Reliability Statistics of Job Selection Scale

\begin{tabular}{ll}
\hline Cronbach's Alpha & N of Items \\
\cline { 2 - 2 } .900 & 24 \\
\hline
\end{tabular}

According to the descriptive statistics results, $61.2 \%$ (128 student) of respondents were expressed themselves as Type A's and the other $38.7 \%$ (81 student) were Type B's.

When we analyze the scales that were used in this study, we get two main groups (type A's and B's) and an ordinal non-dichotomous data consisting of a spectrum of values (Very Important, Important, Neither Important nor Unimportant, Unimportant, Very Unimportant). Because of the categorical structure of this data, Fisher's exact test was thought to be useful. In addition, as seen on Table- 3 some frequencies are less than or equal to five so it is also reasonable to use Fisher's exact test (Shahbaba, 2012).

Fisher's exact test was developed by Ronald Fisher who also developed the analysis of variance "ANOVA" (Lind, et al. 2005). Fisher published “The Design of Experiments" in 1935. In this book Fisher outlined the "Lady tasting tea", a famous design of experiments statistical randomized experiment which uses Fisher's exact test and is the original exposition of Fisher's notion of a null hypothesis (Fisher, 1971).

In order to answer the research questions with Fisher's exact test, the first main hypothesis was developed;

$\mathrm{H}_{1.0}$ : Personality type and degree of importance of motivators of job selection decision are independent.

$\mathrm{H}_{1.1}$ : Personality types and degree of importance of motivators of job selection decision aren't independent.

This hypothesis was tested for each 24 motivator items. For example, one of motivators of job selection decision is "participation in decision making". The hypothesis that was tested for this item is; 
$\mathrm{H}_{1.1 .0}$ : Personality type and degree of importance of participation in decision making are independent.

$\mathrm{H}_{1.1 .1}$ : Personality type and degree of importance of participation in decision making aren't independent.

Fisher's exact test was used for this hypothesis and as a result the null hypothesis was rejected $\left(\mathrm{H}_{1.1 .1}\right.$ was supported). The other motivators of job selection decision that aren't independent with personality type are listed in Table-3.

Table 3: Motivators of Job Selection Decision Scale and Cross Tables

\section{Items of job \\ selection \\ Scale}

Cross Tables

\begin{tabular}{|c|c|c|c|c|c|c|c|c|c|}
\hline \multirow{3}{*}{$\begin{array}{l}\text { Participation } \\
\text { in Decision } \\
\text { Making }\end{array}$} & \multicolumn{9}{|c|}{ Crosstab } \\
\hline & & & & \multicolumn{5}{|c|}{ Degne of Inportance for Purticipation in Decivion Maling } & \multirow[b]{2}{*}{ Total } \\
\hline & & & & 1,00 & 2,00 & 3,00 & 4,00 & 5,00 & \\
\hline & Personality & Type & Count & 1 & 3 & 14 & 40 & 23 & B1 \\
\hline & types & B & \% within Personality types & $12 \%$ & $3,7 \%$ & $17,3 \%$ & $49,4 \%$ & $28.4 \%$ & $100,0 \%$ \\
\hline & & & $\%$ within Item & $100,0 \%$ & $100,0 \%$ & $60,9 \%$ & $35,7 \%$ & $32.9 \%$ & $38.8 \%$ \\
\hline & & Type & Count & 0 & 0 & 9 & 72 & 47 & 128 \\
\hline & & A & \% within Personality types & $0 \%$ & $0 \%$ & $7,0 \%$ & $56,3 \%$ & $36,7 \%$ & $100,0 \%$ \\
\hline & & & 8 within litem & $0 \%$ & $0 \%$ & $39,1 \%$ & $64,3 \%$ & $67,1 \%$ & $61,2 \%$ \\
\hline & Total & & Coumt & 1 & 3 & 23 & 112 & 70 & 209 \\
\hline & & & $\%$ within Personality types & $5 \%$ & $1,4 \%$ & $11,0 \%$ & $53,6 \%$ & $33,5 \%$ & $100,0 \%$ \\
\hline & & & $\%$ within Item & $100,0 \%$ & $100,0 \%$ & $100,0 \%$ & $100,0 \%$ & $100,0 \%$ & $100,0 \%$ \\
\hline
\end{tabular}

\section{Opportunity for Personal}

Growth and Development

\begin{tabular}{|c|c|c|c|c|c|c|c|c|}
\hline \multicolumn{9}{|c|}{ Crosstab } \\
\hline & & & \multicolumn{5}{|c|}{$\begin{array}{c}\text { Degree of Inportance for Opportumity fou Persocsl Gronth } \\
\text { and Development }\end{array}$} & \multirow[b]{2}{*}{ Total } \\
\hline & & & 1,00 & 2,00 & 3,00 & 4,00 & $5, \infty 0$ & \\
\hline Personality & Type & Count & 1 & 1 & 8 & 38 & 33 & 81 \\
\hline \multirow[t]{5}{*}{ types } & $\mathrm{B}$ & \%o within Persomality types & $1,2 \%$ & $1,2 \%$ & $9,9 \%$ & $45,9 \%$ & $40,7 \%$ & $100,0 \%$ \\
\hline & & $\%$ mithin Item & $100,0 \%$ & $50,0 \%$ & $53,3 \%$ & $45,8 \%$ & $30,6 \%$ & $38,8 \%$ \\
\hline & $\mathrm{T}_{\mathrm{y}}$ & Court & 0 & 1 & 7 & 45 & 75 & 128 \\
\hline & A & $\%$ mithin Persomality types & $.0 \%$ & $.8 \%$ & $5,5 \%$ & $35,2 \%$ & $58,6 \%$ & $100,0 \%$ \\
\hline & & $\%$ within Item & $0 \%$ & $50,0 \%$ & $46,7 \%$ & $54,2 \%$ & 69,45 & $61,2 \pi$ \\
\hline \multirow[t]{3}{*}{ Total } & & Count & 1 & 2 & 15 & 83 & 108 & 209 \\
\hline & & $\%$ mithin Perconality types & $5 \%$ & $1,0 \%$ & $7,2 \%$ & $39,7 \%$ & $517 \%$ & $100,0 \%$ \\
\hline & & $\%$ within Item & $100,0 \%$ & $100.0 \%$ & $100,0 \%$ & $100.0 \%$ & $1000 \%$ & $100,0 \%$ \\
\hline
\end{tabular}

Sense of Achievement
Crosstab

\begin{tabular}{|c|c|c|c|c|c|c|c|}
\hline & & & \multicolumn{4}{|c|}{$\begin{array}{c}\text { Degree of Importance for Sense of } \\
\text { Achievement }\end{array}$} & \multirow[b]{2}{*}{ Total } \\
\hline & & & 2,00 & 3,00 & 4.00 & 5,00 & \\
\hline \multirow{6}{*}{$\begin{array}{l}\text { Personality } \\
\text { types }\end{array}$} & Type & Count & 0 & 10 & 40 & 31 & 81 \\
\hline & $B$ & $\%$ within Personality types &, $0 \%$ & $12,3 \%$ & $49,4 \%$ & $38,3 \%$ & $100,0 \%$ \\
\hline & & \% within Item & $.0 \%$ & $66,7 \%$ & $47,6 \%$ & $28,4 \%$ & $38,8 \%$ \\
\hline & Type & Count & 1 & 5 & 44 & 78 & 128 \\
\hline & A & $\%$ within Personality types & $8 \%$ & $3,9 \%$ & $34,4 \%$ & $60,9 \%$ & $100,0 \%$ \\
\hline & & $\%$ within Item & $100,0 \%$ & $33,3 \%$ & $52,4 \%$ & $71,6 \%$ & $61,2 \%$ \\
\hline \multirow[t]{3}{*}{ Total } & & Count & 1 & 15 & 84 & 109 & 209 \\
\hline & & \% within Personality types & $5 \%$ & $72 \%$ & $40,2 \%$ & $52,2 \%$ & $100,0 \%$ \\
\hline & & $\%$ within Item & $100,0 \%$ & $100,0 \%$ & $100,0 \%$ & $100,0 \%$ & $100,0 \%$ \\
\hline
\end{tabular}




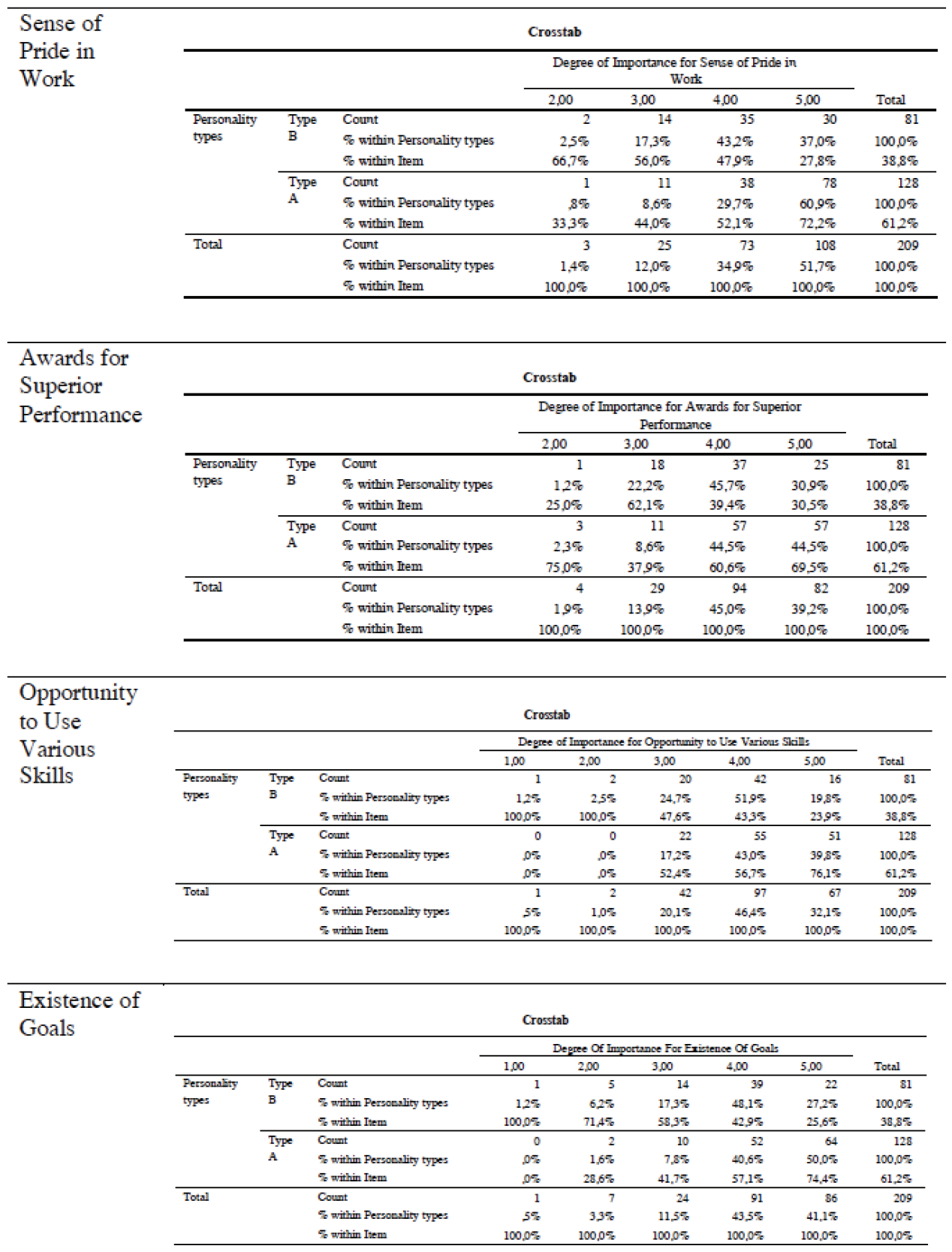


According to Fisher's exact test results, the importance of seven motivators out of 24 ("Participation in decision making", "opportunity for personal growth and development", "sense of achievement", "sense of pride in work", "awards for superior performance", "opportunity to use various skills" and "existence of goals") may vary depending on personality type.

In order to answer the research question and control the results of Fisher's exact test; the second main hypothesis was developed and t-test method was selected to analyze potential difference between personality types about the motivators that effect to job selection decisions.

$\mathrm{H}_{2.0}$ : There isn't a significant difference in degree of importance of each motivator of job selection decision between students who have Type-A personality and who have Type-B personality.

$\mathrm{H}_{2.1}$ : There is a significant difference in degree of importance of each motivator of job selection decision between students who have Type-A personality and who have Type-B personality.

We used t-test for this hypothesis and for all 24 sub-hypotheses and as a result $\mathrm{H}_{2.0}$ was rejected for 11 motivators $\left(\mathrm{H}_{2.1}\right.$ was supported for 11 motivators). The group statistics and t-test results of them are listed in Table- 4 and Table-5.

Table 4: Group Statistics

\begin{tabular}{llllll}
\hline & Personality & $\mathrm{N}$ & Mean & $\begin{array}{l}\text { Std. } \\
\text { Deviation }\end{array}$ & $\begin{array}{l}\text { Std. Error } \\
\text { Mean }\end{array}$ \\
\hline Participation in decision making & Type B & 81 & 4.0000 & .85147 & .09461 \\
& Type A & 128 & 4.2969 & .59339 & .05245 \\
\hline Autonomy in my job & Type B & 81 & 4.0247 & .79018 & .08780 \\
& Type A & 128 & 4.2656 & .73693 & .06514 \\
\hline Opportunity for personalgrowth and development & Type B & 81 & 4.2469 & .78312 & .08701 \\
& Type A & 128 & 4.5156 & .63969 & .05654 \\
\hline Sense of achievement & Type B & 81 & 4.2593 & .66667 & .07407 \\
& Type A & 128 & 4.5547 & .61232 & .05412 \\
\hline Sense of pride in work & Type B & 81 & 4.1481 & .79232 & .08804 \\
& Type A & 128 & 4.5078 & .68730 & .06075 \\
\hline Responsibility in my job & Type B & 81 & 4.0617 & .79602 & .08845 \\
& Type A & 128 & 4.3438 & .70362 & .06219 \\
\hline Awards for superior performance & Type B & 81 & 4.0617 & .76396 & .08488 \\
& Type A & 128 & 4.3125 & .72904 & .06444 \\
\hline Opportunity to use various skills & Type B & 81 & 3.8642 & .80239 & .08915 \\
& Type A & 128 & 4.2266 & .72323 & .06393 \\
\hline Sense of contribution to society & Type B & 81 & 4.0494 & .78901 & .08767 \\
& Type A & 128 & 4.2891 & .82436 & .07286 \\
\hline Existence of goals & Type B & 81 & 3.9383 & .89925 & .09992 \\
& Type A & 128 & 4.3906 & .70134 & .06199 \\
\hline Feedback on my performance & Type B & 81 & 4.0494 & .92061 & .10229 \\
& Type A & 128 & 4.3125 & .73976 & .06539 \\
\hline
\end{tabular}


Table 5: T-Test Results

Independent Samples Test

\begin{tabular}{|c|c|c|c|c|c|c|c|c|c|c|}
\hline & & $\begin{array}{l}\text { Levene } \\
\text { Equality }\end{array}$ & $\begin{array}{l}\text { for } \\
\text { iances }\end{array}$ & \multirow[b]{3}{*}{$\mathrm{t}$} & \multicolumn{4}{|c|}{ t-test for Equality of Means } & & \\
\hline & & \multirow[b]{2}{*}{$\mathbf{F}$} & \multirow[b]{2}{*}{ Sig. } & & & Sig- & Mesn & \multirow{2}{*}{$\begin{array}{l}\text { Std. Enor } \\
\text { Difference }\end{array}$} & \multicolumn{2}{|c|}{$\begin{array}{c}95 \% \\
\text { Confidence } \\
\text { Interval of the } \\
\text { Difference }\end{array}$} \\
\hline & & & & & df & (2-triled) & Difference & & Loner & Upper \\
\hline \multirow[t]{2}{*}{$\begin{array}{l}\text { Participation In } \\
\text { Decision Maling }\end{array}$} & $\begin{array}{l}\text { Equal wariunos } \\
\text { assumed }\end{array}$ & .642 & .424 & $-2,968$ & 207 &, 003 & -29688 &, 10002 & -4941 &,- 0997 \\
\hline & $\begin{array}{l}\text { Equal warisnoes } \\
\text { not assumed }\end{array}$ & & & $-2,744$ & 129,053 &, 007 & -29688 &, 10817 & -5109 & $-0,29$ \\
\hline \multirow[t]{2}{*}{$\begin{array}{l}\text { Autonany In My } \\
\text { Job }\end{array}$} & $\begin{array}{l}\text { Equal wanimoes } \\
\text { ssumed }\end{array}$ & 1,762 & 186 & $-2,239$ & 207 & 026 & -24093 &, 10761 & -4531 &,- 0208 \\
\hline & $\begin{array}{l}\text { Equal wariunoes } \\
\text { not asoumed }\end{array}$ & & & $-2,204$ & 161,483 & 029 & -24093 &, 10932 & -4568 &,- 0251 \\
\hline $\begin{array}{l}\text { Opporturity for } \\
\text { For Personal }\end{array}$ & $\begin{array}{l}\text { Equal wariunces } \\
\text { assumed }\end{array}$ & .742 & .390 & $-2,709$ & 207 &, 007 & -26871 & 09919 & -4643 & -0732 \\
\hline $\begin{array}{l}\text { Grouth And } \\
\text { Dewelopment }\end{array}$ & $\begin{array}{l}\text { Equal warimoes } \\
\text { not assumed }\end{array}$ & & & $-2,589$ & 145,483 & 011 & -26871 & 10377 &,- 4738 & -0536 \\
\hline \multirow[t]{2}{*}{$\begin{array}{l}\text { Senve of } \\
\text { Achievement }\end{array}$} & $\begin{array}{l}\text { Equal warinoses } \\
\text { asumed }\end{array}$ & 311 & .578 & $-3,283$ & 207 &, 001 & -29543 &, 09000 &,- 4729 &,- 1180 \\
\hline & $\begin{array}{l}\text { Equal warisnoes } \\
\text { pot assumed }\end{array}$ & & & $-3,220$ & 159,569 &, 002 & -29543 &, 09174 & -.4766 &,- 1142 \\
\hline \multirow[t]{2}{*}{$\begin{array}{l}\text { Senve of Pride In } \\
\text { Work }\end{array}$} & $\begin{array}{l}\text { Equal variunoes } \\
\text { asumed }\end{array}$ & 312 & .577 & $-3,472$ & 207 &, 001 & -35966 &, 10960 & -5639 & -1554 \\
\hline & $\begin{array}{l}\text { Equal warinoes } \\
\text { not asoumed }\end{array}$ & & & $-3,363$ & 152,539 &, 001 & -95966 &, 10696 & -5710 &,- 1483 \\
\hline \multirow[t]{2}{*}{$\begin{array}{l}\text { Respousibility In } \\
\text { My Job }\end{array}$} & $\begin{array}{l}\text { Equal wariunces } \\
\text { assumed }\end{array}$ & 356 & .551 & $-2,682$ & 207 &, 008 & -28202 & .10516 & -4894 & -0747 \\
\hline & $\begin{array}{l}\text { Equal variunces } \\
\text { not assumed }\end{array}$ & & & $-2,608$ & 154,824 &, 010 & -28202 &, 10812 & -4956 & -0584 \\
\hline $\begin{array}{l}\text { Amands For } \\
\text { Saperior }\end{array}$ & $\begin{array}{l}\text { Equal varinoses } \\
\text { ascumed }\end{array}$ & 289 & .592 & $-2,378$ & 207 & 018 & -25077 & .10545 & -4587 & -0429 \\
\hline Performance & $\begin{array}{l}\text { Equal variances } \\
\text { pot asgumed }\end{array}$ & & & $-2,353$ & 164,383 &, 020 & -25077 & .10657 & -4612 & -0403 \\
\hline $\begin{array}{l}\text { Opporturity To } \\
\text { Use Various }\end{array}$ & $\begin{array}{l}\text { Equal waninots } \\
\text { ssumed }\end{array}$ & 179 & .673 & $-3,381$ & 207 &, 001 & -96236 &, 10717 & -5736 &,- 1511 \\
\hline Skills & $\begin{array}{l}\text { Equal warimoes } \\
\text { not assumed }\end{array}$ & & & $-3,303$ & 157,226 &, 001 & -96236 & 10970 & -5790 &,- 1457 \\
\hline $\begin{array}{l}\text { Senve of } \\
\text { Costribution To }\end{array}$ & $\begin{array}{l}\text { Equal varimoses } \\
\text { asumed }\end{array}$ & 2,246 & .136 & $-2,082$ & 207 &, 099 & -23968 & .11513 & -4667 & -0127 \\
\hline Society & $\begin{array}{l}\text { Equal wariunoes } \\
\text { not asoumed }\end{array}$ & & & $-2,103$ & 175,844 &, 037 & -23968 & 11399 & -4647 & -0147 \\
\hline \multirow[t]{2}{*}{$\begin{array}{l}\text { Eristence of } \\
\text { Gouls }\end{array}$} & $\begin{array}{l}\text { Equal wanimets } \\
\text { assumed }\end{array}$ & .158 & .692 & $-4,065$ & 207 &, 000 & -45235 &, 11128 &,- 6717 & -2330 \\
\hline & $\begin{array}{l}\text { Equal warionoes } \\
\text { not asoumed }\end{array}$ & & & $-3,247$ & 140,343 &, 000 &,--45235 & .11758 & -.6848 & -2199 \\
\hline \multirow[t]{2}{*}{$\begin{array}{l}\text { Feedbuelk on My } \\
\text { Performance }\end{array}$} & $\begin{array}{l}\text { Equal variunces } \\
\text { ssumed }\end{array}$ & .467 & .495 & $-2,275$ & 207 &, 024 & -26912 & .11563 & -4911 & -00351 \\
\hline & $\begin{array}{l}\text { Equal variunces } \\
\text { pot asgumed }\end{array}$ & & & $-2,167$ & 143,628 &, 032 & -26312 & 12140 & -5031 &,- 0231 \\
\hline
\end{tabular}

According to t-test results, the importance of 11 motivators out of 24; 'Participation in decision making', 'autonomy in my job', 'opportunity for personal growth and development', 'sense of achievement', 'sense of pride in work, 'responsibility in my job, 'awards for superior performance', 'opportunity to use various skills', 'sense of contribution to society', 'existence of goals' and 'feedback on my performance' may vary depending on personality type.

When we compare the results of Fisher's exact test and t-test; the seven motivators found in Fisher's exact test are all located in the t-test results: ('Participation in decision making', 'opportunity for personal growth and development', 'sense of achievement', 'sense of pride in work', 'awards for superior performance', 'opportunity to use various skills' and 'existence of goals'). Thus it can be said that, the results are consistent with each other. 
In addition to the aforementioned tests, Kappa coefficient was used to analyze the level of agreement between personality type and degree of importance of motivators that effect job selection decisions.

The modes of 24 job selection items for both Type A and B groups were calculated in order to calculate Kappa coefficient. The results are shown in Table-6 and Table-7.

Table 6. Type A and Type B Crosstabulation

\begin{tabular}{|c|c|c|c|c|}
\hline & & \multicolumn{2}{|c|}{ Type B } & \multirow[t]{2}{*}{ Total } \\
\hline & & 4,00 & 5,00 & \\
\hline \multirow[t]{2}{*}{ Type A } & 4,00 & 8 & 0 & 8 \\
\hline & 5,00 & 12 & 4 & 16 \\
\hline Total & & 20 & 4 & 24 \\
\hline
\end{tabular}

Table 7. Symmetric Measures

\begin{tabular}{llllll}
\hline & & Asymp. Std. & \\
& & Value & Error(a) & Approx. T(b) & Approx. Sig. \\
\hline $\begin{array}{l}\text { Measure of Agreement } \\
\text { N of Valid Cases }\end{array}$ & Kappa & .182 & .096 & 1.549 & .121 \\
\hline
\end{tabular}

a. Not assuming the null hypothesis.

b. Using the asymptotic standard error assuming the null hypothesis.

The Kappa coefficient of personality types about the motivators of job selection decision is calculated as 0.182 . But this result is not significant. According to kappa coefficient results, it can be said that; there isn't agreement between Type A's and Type B's about the importance of motivators that effect their job selection decisions because the Approx. Sig. value is higher than 0.05.

\section{Conclusion}

This study explores whether the given importance of motivators that effect potential job selection decisions of university students changed depending on their personality type. An empirical research was conducted in order to answer this research question. All participants were Bachelor students in the Faculty of Business Administration of Marmara University, Turkey. Data collection was accomplished through a three-part questionnaire. The first part of the questionnaire was the demographic variables, the second part was related with Type-A and Type-B personality types and the last part was related with the motivators that effect students' potential job selection decisions.

In this study, a possible and significant difference in the given importance of motivators that effect potential job selection decisions of university students who have Type A personality and 
who have Type B personality is tested. According to the results of statistical analyses, it is found that students with Type-A Behavior Pattern tended to give more importance to some motivators which effect their potential job selection decisions. Respectively all three statistical methods that were used in this study gave consistent results. Firstly, Fisher's exact test was used to understand whether there is an independency between two personality groups. It was reasonable to use Fisher's exact test because some frequencies (in given importance) are less than or equal to five. As a result of Fisher's exact test, significant independencies were found in seven motivators between the two personality pattern groups.

In addition to Fisher's exact test, t-test method was used to analyze potential difference between personality types about the motivators that effect to job selection decisions. According to t-test results, the importance of 11 motivators out of 24 (Table-8) may vary depending on personality type. When we compare the results of Fisher's exact test and t-test; the seven motivators found in Fisher's exact test are all located in the t-test results. Thus it can be said that, the results of two methods are consistent with each other.

Table 8: Comparison of the results with literature

\begin{tabular}{ll}
\hline $\begin{array}{l}\text { Type-A's give significantly more importance } \\
\text { these motivators that effect job selection decision in }\end{array}$ & $\begin{array}{l}\text { Similar expressions and/or findings describing Type-A } \\
\text { Behavior Pattern in the literature } \\
\text { comparison with Type-B's }\end{array}$ \\
\hline $\begin{array}{l}\text { Participation in decision making } \\
\text { Autonomy in my job }\end{array}$ & $\begin{array}{l}\text { Fisher, } 2001 \text { (a strong desire to control their environment) } \\
\text { Sager, } 1991 \text { (preference of working alone) }\end{array}$ \\
Opportunity for personal growth and development & $\begin{array}{l}\text { Rosenman and Friedman, 1961 (desire for advancement) } \\
\text { Rosenman and Friedman, 1961; Bartkus, et al. 1989; }\end{array}$ \\
Sense of achievement & $\begin{array}{l}\text { Sager, 1991; Lee, et al. 1996; Fisher, 2001; Watson, et al. } \\
\text { 2006; Hanif and Sultan, 2011; Erden, et al. 2013 }\end{array}$ \\
Sense of pride in work & Bartkus, et al. 1989; Sager, 1991 (high commitment) \\
Responsibility in my job & Bartkus, et al. 1989; Sager, 1991; Lee, et al. 1996; Stewart- \\
Awards for superior performance & Belle and Lust, 1999 (job involvement) \\
Opportunity to use various skills & Rosenman and Friedman, 1961 (desire for recognition) \\
Sense of contribution to society & - \\
Existence of goals & - \\
Feedback on my performance & Bartkus, et al. 1989; Watson, et al. 2006 \\
\hline
\end{tabular}

In addition to the aforementioned tests, Kappa coefficient was used to analyze the level of agreement between personality type and degree of importance of motivators that effect job selection decisions. The significant differences that were found at Fisher's exact test and t-test may bring to mind these questions; "If there are significant differences in only 7 or 11 motivators, what about the other 17 or 13 motivators? Is there a general agreement between the two personality pattern groups for those 17 or 13 motivators?" By using Kappa coefficient it can be easily defined whether a general agreement between the two types of personality groups for all of the motivators in general. As a result, a significant agreement could not found between the two patterns (Type-A's and Type-B's). 
When we analyze the motivators that Type-A's give significantly more importance when compared to Type B's, we can see accordance with the similar expressions and/or findings describing Type-A Behavior Pattern in the literature (Table-8). Therefore, it can be said that, the results support the literature.

'Participation in decision making' motivator that effect job selection decision, can be considered as synonymous with Fisher's "a strong desire to control their environment" (2001). 'Autonomy in my job' motivator that effect job selection decision, can be considered as synonymous with Sager's "preference of working alone" (1991). Opportunity for personal growth and development motivator that effect job selection decision, can be considered as synonymous with Rosenman and Friedman's "desire for advancement" (1961). 'Sense of achievement' motivator that effect job selection decision, exactly take place in Rosenman and Friedman, 1961; Bartkus, et al. 1989; Sager, 1991; Lee, et al. 1996; Fisher, 2001; Watson, et al. 2006; Hanif and Sultan, 2011; Erden, et al. 2013. 'Sense of pride in work' motivator that effect job selection decision, exactly take place in Bartkus, et al. 1989; and can be considered as synonymous with "high commitment" in Sager, 1991. 'Responsibility in my job' motivator that effect job selection decision, exactly take place in Bartkus, et al. 1989; Sager, 1991; Lee, et al. 1996; and can be considered as synonymous with "job involvement" in Stewart-Belle and Lust, 1999. 'Awards for superior performance' motivator that effect job selection decision, can be considered as synonymous with Rosenman and Friedman's "desire for recognition" (1961). Lastly 'Existence of goals' motivator that effect job selection decision, exactly take place in Bartkus, et al. 1989 and Watson, et al. 2006.

As a contribution to the literature; it may be said that, 'opportunity to use various skills', 'sense of contribution to society' and 'feedback on his/her performance' may also affect the decisions of Type-A's and maybe those desires reveal some unknowns about this behavior pattern.

When taken as a general proposition those 11 motivators that significantly more important for Type-A's evoke the main characteristics of Type-A Behavior Pattern. For example, in the literature Type-A's has been found to expand more effort and outperform Type-B's. This is very logical to understand why they give more importance to the motivators; 'Opportunity for personal growth and development,' 'Sense of achievement', 'Awards for superior performance,' 'Opportunity to use various skills,' 'Existence of goals' and 'Feedback on my performance' because these motivators need more and more effort and they may provide superior performance in work.

It is recommended that further researches can be conducted on the other side of the table, and investigate the possible effects of these significant differences in the human resources recruitment processes, especially in terms of recruiters' perceptions.

\section{References}

Aycan Z. and Fikret-Pasa S., 2003. Career Choices, Job Selection Criteria, and Leadership Preferences in a Transitional Nation: The Case of Turkey. Journal of Career Development, Vol.30, No.2, pp.129-144.

Baltaş, Z. and Baltaş A., 2012. Stres ve Başaçıkma Yolları. Istanbul: Remzi Publications. 
Bartkus, K.R., Peterson, M.F. and Bellenger, D.N., 1989. Type A Behavior, Experience, and Salesperson Performance. Journal of Personal Selling \& Sales Management, Vol.IX, pp.11-18.

Begley, T.M. and Boyd, D.P., 1987. A Comparison of Entrepreneurs and Managers of Small Business Firms. Journal of Management, Vol.13, No.1, pp.99-108.

Billing, T.K. and Steverson, P., 2013. Moderating role of Type-A personality on stress-outcome relationships. Management Decision, Vol. 51, No. 9, pp. 1893-1904

Byrne, D.G. and Reinhart, M.I., 1989. Work characteristics, occupational achievement and the Type A behaviour pattern. Journal of Occupational Psychology, 62, pp.123-134.

Corrigall, E.A., 2008. Welfare states, families, job attribute preferences, and work. Cross Cultural Management, Vol.15, No.2, pp.144-161

Erden, N.S., Toplu, D. and Yaşlığlu, M.M., 2013. Mediating Effects of Job Demands on the Relationship Between Type A Personality and Workaholism: A Study on Turkish Workers. The IUP Journal of Organizational Behavior, Vol.XII, No.2, pp.7-19.

Eren, E., 2000. Örgütsel Davranışve Yönetim Psikolojisi, $6^{\text {th }}$ ed. Istanbul: Beta Publications.

Fisher, R.A., 1971. The Design of Experiments. $8^{\text {th }}$ ed. New York: Hafner Publishing Company.

Fisher, R.T., 2001. Role Stress, the Type A Behavior Pattern, and External Auditor Job Satisfaction and Performance. Behavioral Research In Accounting, Vol.13, pp.143-170.

Hanif, A. and Sultan, S., 2011. Type A-B Personality and Locus of Control: A Combined Factor Determining Job Satisfaction. IBA Business Review, Vol.6, No.2, pp.90-96.

Kanungo R.N. and Hartwick, J., 1987. An Alternative to the Intrinsic-Extrinsic Dichotomy of Work Rewards. Journal of Management, Vol.13, No.4, pp.751-766.

Kulkarni, M. and Nithyanand, S., 2013. Social influence and job choice decisions. Employee Relations, Vol.35, No.2, pp.139-156.

Lee, C., Jamieson, L.F., Earley, P.C., 1996. Beliefs and fears and Type A behavior: Implications for academic performance and psychiatric health disorder symptoms. Journal of Organizational Behavior, Vol.17, pp.151-177.

Lind, D.A., Marchal, W.G., Wathen, S.A., 2005. Statistical Techniques in Business and Economics. New York: McGraw-Hill.

Nahavandi, A. Mizzi, P.J. and Malekzadeh, A.R., 1992. Executives' Type A Personality as a Determinant of Environmental Perception and Firm Strategy. Journal of Social Psychology, Vol.132, Issue.1, pp.59-67.

Robbins, S. P., 1998. Organizational Behavior: Concepts, Controversies, Applications, $8^{\text {th }}$ ed. Prentice Hall.

Rosenman, R.H. and Friedman, M., 1961. Association of Specific Behavior Pattern in Women with Blood and Cardiovascular Findings. Circulation, Vol.XXIV, pp.1173-1184.

Sager, J.K., 1991. Type A Behavior Pattern (TABP) Among Salespeople And Its Relationship to Job Stress. Journal of Personal Selling \& Sales Management, Vol.XI, No.2, pp.1-14.

Sameen, S. and Burhan, M., 2014. Creativity and Its Link with Personality Type A/B in Students. Journal of Business Studies Quarterly, Vol.6, No.1, pp.156-166.

Shahbaba, B., 2012. Biostatistics with R: An Introduction to Statistics Through Biological Data. New York: Springer.

Stewart-Belle S. and Lust, J.A., 1999. Career Movement of Female Employees Holding Lower-Level Positions: An Analysis of The Impact of The Type A Behavior Pattern. Journal of Business and Psychology, Vol.14, No.1, pp.187-197.

Watson, W.E., Minzenmayer, T. and Bowler, M., 2006. Type A Personality Characteristics and the Effect on Individual and Team Academic Performance. Journal of Applied Social Psychology, 36, 5, pp.11101128 . 
